\title{
Mandado de Segurança Coletivo no Pensamento de J. J. Calmon de Passos
}

\author{
Collective Writ of Mandamus in the Thinking of J. J. Calmon de Passos
}

Marco Félix Jobim

'Pontifícia Universidade Católica do Rio Grande do Sul - PUCRS, Brasil

\begin{abstract}
Resumo
O artigo tem a intenção de expor o pensamento de J.J. Calmon de Passos naquilo que pensava sobre a ação constitucional do mandado de segurança coletivo. Para tanto, será estudada sua obra específica sobre o tema, imergindo em suas ideias e as resgatando para demonstrar sua contemporaneidade às novas gerações de processualistas.

Palavras-chave: Mandado de Segurança Coletivo; Ação Constitucional; J. J. Calmon de Passos
\end{abstract}

\begin{abstract}
The article intends to expose the thinking ofJ.J. Calmon de Passos in what he thought about the constitutional action of the collective writ of mandamus. For that, his specific work on the theme will be studied, immersing in his ideas and rescuing them to demonstrate his contemporaneity to the new generations of processualists.
\end{abstract}

Keywords: Collective Writ of Mandamus; Constitutional Action; J. J. Calmon de Passos

\section{Introdução}

Poucos são os processualistas que gozam de tanto prestígio como J.J. Calmon de Passos ${ }^{1}$. Estudioso não só do direito processual, Calmon tem, em suas obras, pensamentos singulares que movimentam intensos debates, apesar de, infelizmente, não partilhar mais desse plano com as novas gerações que se formam atualmente.

Um desses momentos, em que se debateu² e se homenageou o professor e sua obra, foi no encontro da ANNEP ${ }^{3}$ - Associação Norte e Nordeste de Professores de Processo ${ }^{4}$, por via remota em

1 Professor emérito da Faculdade de Direito da Universidade Federal da Bahia, Livre-docente da Faculdade de Ciências Econômicas da mesma Universidade e atual Coordenador e Professor do Curso de Especialização em Processo da Universidade Salvador - UNIFACS, além de membro da Academia de Letras Jurídicas da Bahia. Brilhou, também, no Ministério Público do Estado, aposentando-se como Procurador de Justiça.

2 A mesa do subscritor do artigo foi a de mandado de segurança, tendo como palestrantes Teresa Arruda Alvim, José Henrique Mouta, Janaína Noleto, Tamyres Tavares e como debatedor Ravi Peixoto.

3 Para conhecer um pouco da história da ANNEP, ver: JOBIM, Marco Félix. Cultura, escolas e fases metodológicas do processo. 4. ed. Porto Alegre: Livraria do Advogado, 2019.

4 As palestras em homenagem ao mestre podem ser assistidas na íntegra, cf. ASSOCIAÇÃO NORTE NORDESTE DE PROFESSORES DE PROCESSO. ANNEP Associação. Canal no YouTube. [S.l.: s.n.], 19 maio 2020. Disponível em: https:// www.youtube.com/channel/UCEtAWMGXrTwabGQ0wxcjdOg. Acesso em: 11 jul. 2020. 
razão da pandemia global do coronavírus em 2020, razão pela qual se agradece a esta instituição, na pessoa de seu atual presidente, o amigo Pedro Henrique Nogueira ${ }^{1}$, assim como da vice-presidente Paula Sarno Braga².

Suas obras são leitura obrigatória ${ }^{3}$, quer seja para concordar, criticar, ou meramente referir como forma de demonstração de uma pesquisa bem realizada academicamente. Quem trabalha, mesmo que atualmente, com o tema das invalidades processuais não pode deixar de citar sua consagrada obra sobre o tema das nulidades ${ }^{4}$, assim como não se pode deixar de fazer referência em qualquer trabalho sobre ação de sua tese reeditada recentemente sobre a temática ${ }^{5}$.

É dele também: Comentários ao Código de Processo Civil (arts. 270-331) ${ }^{6}$; Revisitando o direito, o poder, a justiça e o processo $^{7}$; além de inúmeros artigos doutrinários e outros estudos que podem ser vistos em obras que compilam o material como Ensaios e Artigos $1^{8}$ e $2^{9}$.

Orador nato, algumas de suas palestras podem ser vistas em alguns sites ${ }^{10}$, o que parece ser bastante recomendável para conhecer a forma como expunha suas ideias. Obviamente que essas referências são meramente exemplificativas e não taxativas.

Também é de se afirmar o alcance que a obra de Calmon de Passos teve na vida de muitos processualistas no país, formando gerações. Fredie Didier $\mathrm{Jr}^{11}$. relata um pouco dessa influência, confessando, o que não nunca foi segredo, que sua trajetória acadêmica foi também moldada a partir das leituras do professor baiano, tendo culminado com sua defesa de doutorado ${ }^{12}$ no tema do mestre. De igual forma, Antônio Gidi não deixa de elogiar o jurista baiano quando tem a possibilidade de fazê-lo.

Contudo, o assunto que concerne ao presente artigo aborda outra obra específica do autor, na qual, já numa linha mais ligada ao tema da Constituição e Processo, trabalha com algumas ações constitucionais, sendo, no caso, a que nesse momento interessa, aquela que trabalha com seu pensamento

1 NOGUEIRA, Pedro Henrique. Negócios jurídicos processuais. 4. ed. Salvador: Juspodivm,

2 BRAGA, Paula Sarno. Norma de processo e norma de procedimento: o problema da repartição de competência legislativa no direito constitucional brasileiro. Salvador: Juspodivm, 2015.

3 Além de suas palestras, que demonstravam ser um orador nato, ver a conferência: O QUE é justo? - J.J. Calmon de Passos. 1 vídeo, 1h07min22s. Publicado pelo canal Diego Sousa. [S.l.:

s.n.], 30 dez. 2016. Disponível em: https://www.youtube.com/watch?v=fUAu8DnHEuo. Acesso em: 11 jul. 2020.

4 PASSOS, Calmon. Esboço de uma teoria das nulidades aplicada às nulidades processuais. Rio de Janeiro: Forense, 2001 .

$5 \quad$ PASSOS, J. J. Calmon de. A ação no direito processual civil brasileiro. Salvador: Juspodivm, 2014.

6 PASSOS, J. J. Calmon de. Comentários ao Código de Processo Civil (arts. 270-331). 9. ed. Rio de Janeiro: Forense, 2004, v. 3.

7 PASSOS, J. J. Calmon de. Revisitando o direito, o poder, a justiça e o processo: reflexões de um jurista que trafega na contramão. Salvador: Juspodivm, 2012.

8 PASSOS, J. J. Calmon de. Ensaios e artigos. Salvador: Juspodivm, 2014, v. 1.

9 PASSOS, J. J. Calmon de. Ensaios e artigos. Salvador: Juspodivm, 2016, v. 2.

10 PASSOS,J.J.Calmonde.Oqueéjusto?Palestra.Disponívelem:https: $/$ www.youtube.com/watch?v=fUAu8DnHEuo. Acesso 11 nov. 2020.

11 PASSOS, J. J. Calmon de. A ação no direito processual civil brasileiro. Salvador: Juspodivm, 2014. Assim escreve Fredie no prefácio: "Em 1996, Calmon me convidou par assistir às suas aulas no curso de especialização em direito processual civil, na UFBA. Eu era, então, aluno do quarto ano do bacharelado em direito. Ficamos muito próximos. Calmon emprestoume o seu exemplar deste livro - que continha preciosas anotações, feitas à mão ou datilografadas em papéis avulsos anexados à tese. Devorei o texto. Ele foi a principal fonte de inspiração daquele que se tornaria, quatro anos depois, o meu primeiro artigo publicado em periódico nacional, em que desenvolvo e divulgo o pensamento de Calmon. Em cinco anos, defenderia minha tese de doutoramento sobre os pressupostos processuais e as condições da ação, encerrando, com isso, a primeira etapa da minha formação intelectual, com uma investigação, exatamente, do tema pelo qual iniciei”.

12 Cuja tese rendeu a obra: DIDIERJR., Fredie. Pressupostos processuais e condições da ação: ojuízo de admissibilidade do processo. São Paulo: Saraiva, 2005. 
razão da pandemia global do coronavírus em 2020, razão pela qual se agradece a esta instituição, na pessoa de seu atual presidente, o amigo Pedro Henrique Nogueira ${ }^{5}$, assim como da vice-presidente Paula Sarno Braga ${ }^{6}$.

Suas obras são leitura obrigatória ${ }^{7}$, quer seja para concordar, criticar, ou meramente referir como forma de demonstração de uma pesquisa bem realizada academicamente. Quem trabalha, mesmo que atualmente, com o tema das invalidades processuais não pode deixar de citar sua consagrada obra sobre o tema das nulidades ${ }^{8}$, assim como não se pode deixar de fazer referência em qualquer trabalho sobre ação de sua tese reeditada recentemente sobre a temática9 ${ }^{9}$

É dele também: Comentários ao Código de Processo Civil (arts. 270-331) ${ }^{10}$; Revisitando o direito, o poder, a justiça e o processo"li ; além de inúmeros artigos doutrinários e outros estudos que podem ser vistos em obras que compilam o material como Ensaios e Artigos $1{ }^{12}$ e $2^{13}$.

Orador nato, algumas de suas palestras podem ser vistas em alguns sites ${ }^{14}$, o que parece ser bastante recomendável para conhecer a forma como expunha suas ideias. Obviamente que essas referências são meramente exemplificativas e não taxativas.

Também é de se afirmar o alcance que a obra de Calmon de Passos teve na vida de muitos processualistas no país, formando gerações. Fredie Didier $\mathrm{Jr}^{15}$. relata um pouco dessa influência, confessando, o que não nunca foi segredo, que sua trajetória acadêmica foi também moldada a partir das leituras do professor baiano, tendo culminado com sua defesa de doutorado ${ }^{16}$ no tema do mestre. De igual forma, Antônio Gidi não deixa de elogiar o jurista baiano quando tem a possibilidade de fazê-lo.

Contudo, o assunto que concerne ao presente artigo aborda outra obra específica do autor, na qual, já numa linha mais ligada ao tema da Constituição e Processo, trabalha com algumas ações constitucionais, sendo, no caso, a que nesse momento interessa, aquela que trabalha com seu pensamento

$5 \quad$ NOGUEIRA, Pedro Henrique. Negócios jurídicos processuais. 4. ed. Salvador: Juspodivm,

6 BRAGA, Paula Sarno. Norma de processo e norma de procedimento: o problema da repartição de competência legislativa no direito constitucional brasileiro. Salvador: Juspodivm, 2015.

$7 \quad$ Além de suas palestras, que demonstravam ser um orador nato, ver a conferência: O QUE é justo? - J.J. Calmon de Passos. 1 vídeo, 1h07min22s. Publicado pelo canal Diego Sousa. [S.l.:

s.n.], 30 dez. 2016. Disponível em: https://www.youtube.com/watch?v=fUAu8DnHEuo. Acesso em: 11 jul. 2020.

8 PASSOS, Calmon. Esboço de uma teoria das nulidades aplicada às nulidades processuais. Rio de Janeiro: Forense, 2001.

9 PASSOS, J. J. Calmon de. A ação no direito processual civil brasileiro. Salvador: Juspodivm, 2014.

10 PASSOS, J. J. Calmon de. Comentários ao Código de Processo Civil (arts. 270-331). 9. ed. Rio de Janeiro: Forense, 2004, v. 3.

11 PASSOS, J. J. Calmon de. Revisitando o direito, o poder, a justiça e o processo: reflexões de um jurista que trafega na contramão. Salvador: Juspodivm, 2012.

12 PASSOS, J. J. Calmon de. Ensaios e artigos. Salvador: Juspodivm, 2014, v. 1.

13 PASSOS, J. J. Calmon de. Ensaios e artigos. Salvador: Juspodivm, 2016, v. 2.

14 PASSOS,J.J.Calmonde.Oqueéjusto?Palestra.Disponívelem:https: $/ /$ www.youtube.com/watch?v=fUAu8DnHEuo. Acesso 11 nov. 2020.

15 PASSOS, J. J. Calmon de. A ação no direito processual civil brasileiro. Salvador: Juspodivm, 2014. Assim escreve Fredie no prefácio: "Em 1996, Calmon me convidou par assistir às suas aulas no curso de especialização em direito processual civil, na UFBA. Eu era, então, aluno do quarto ano do bacharelado em direito. Ficamos muito próximos. Calmon emprestoume o seu exemplar deste livro - que continha preciosas anotações, feitas à mão ou datilografadas em papéis avulsos anexados à tese. Devorei o texto. Ele foi a principal fonte de inspiração daquele que se tornaria, quatro anos depois, o meu primeiro artigo publicado em periódico nacional, em que desenvolvo e divulgo o pensamento de Calmon. Em cinco anos, defenderia minha tese de doutoramento sobre os pressupostos processuais e as condições da ação, encerrando, com isso, a primeira etapa da minha formação intelectual, com uma investigação, exatamente, do tema pelo qual iniciei”.

16 Cuja tese rendeu a obra: DIDIERJR., Fredie. Pressupostos processuais e condições da ação: ojuízo de admissibilidade do processo. São Paulo: Saraiva, 2005. 
no mandado de segurança coletivo ${ }^{17}$. É de se registrar que há uma profusão de livros ${ }^{18}$ sobre o tema, quer na temática individual ou coletiva, mas não há como deixar de referir que Calmon escreve seu texto pouco tempo após a Constituição Federal ser promulgada, o que será algumas frases à frente.

É sempre bom frisar que o texto irá, meramente, expor sobre o

pensamento do jurista baiano no ano de 1989, um ano somente após o advento da Constituição Federal $^{19}$, ainda sobre a égide do Código de Processo Civil de $1973^{20}$, muito distante, também, da atual Lei n. 12.016/2009² - que dispõe sobre o mandado de segurança individual e coletivo -, assim como do $\mathrm{CPC} / 2015^{22}$.

\section{O mandado de segurança na visão de J. J. Calmon de Passos}

A obra objeto do estudo que neste momento se apresente aborda a ação constitucional do mandado de segurança coletivo, não sendo esquecido que Calmon já trabalhou com o tema do individual $\mathrm{em}$ outros textos ${ }^{23}$, tendo assim definindo seus capítulos:

Exegese do inciso LXX do art. $5^{\circ}$ da Constituição Federal; Pressupostos específicos do mandado de segurança coletivo; Pressupostos processuais e as condições da ação do mandando de segurança coletivo; Decadência do

17 PASSOS, J. J. Calmon de. Mandado de segurança coletivo, mandado de injunção, habeas data: constituição e processo. Rio de Janeiro: Forense, 1989.

18 Aqui apenas se faz três referências, pois o texto produzido é sobre Calmon de Passos. ZANETI

Jr., Hermes. O 'novo' mandado de segurança coletivo. Salvador: JusPODIVM, 2013; QUEIROZ, Pedro Gomes de. Mandado de segurança: propostas para duração razoável e efetividade. Salvador: JusPODIVM, 2018; ARAÚJO, José Henrique Mouta. Mandado de segurança. 8. Ed. Salvador: JusPODIVM, 2021.

19 BRASIL. Constituição (1988). Constituição da República Federativa do Brasil de 1988.

Brasília, 1988. Disponível em: http://www.planalto.gov.br/ccivil_03/constituicao/constituicao.htm. Acesso em: 11 jul. 2020.

20 BRASIL. Lei n. 5.869, de 11 de janeiro de 1973. Institui o Código de Processo Civil. Brasília, 1973. Disponível em: http://www.planalto.gov.br/ccivil 03/leis/15869impressao.htm. Acesso em: 11 jul. 2020.

21 BRASIL. Lei n. 12.016, de 7 de agosto de 2009. Disciplina o mandado de segurança individual e coletivo e dá outras providências. Brasília, 2009. Disponível em: http://www.planalto.gov.br/ccivil 03/_ato2007-2010/2009/lei/112016.htm. Acesso em: 11 jul. 2020. Aqui alguns dispositivos da lei específicos sobre mandado de segurança coletivo, para que o leitor possa compara com o pensamento de Calmon: "Art. 21. O mandado de segurança coletivo pode ser impetrado por partido político com representação no Congresso Nacional, na defesa de seus interesses legítimos relativos a seus integrantes ou à finalidade partidária, ou por organização sindical, entidade de classe ou associação legalmente constituída e em funcionamento há, pelo menos, 1 (um) ano, em defesa de direitos líquidos e certos da totalidade, ou de parte, dos seus membros ou associados, na forma dos seus estatutos e desde que pertinentes às suas finalidades, dispensada, para tanto, autorização especial. Parágrafo único. Os direitos protegidos pelo mandado de segurança coletivo podem ser: I - coletivos, assim entendidos, para efeito desta Lei, os transindividuais, de natureza indivisível, de que seja titular grupo ou categoria de pessoas ligadas entre si ou com a parte contrária por uma relação jurídica básica; II - individuais homogêneos, assim entendidos, para efeito desta Lei, os decorrentes de origem comum e da atividade ou situação específica da totalidade ou de parte dos associados ou membros do impetrante. Art. 22. No mandado de segurança coletivo, a sentença fará coisa julgada limitadamente aos membros do grupo ou categoria substituídos pelo impetrante. § 1o O mandado de segurança coletivo não induz litispendência para as ações individuais, mas os feitos da coisa julgada não beneficiarão o impetrante a título individual se não requerer a desistência de seu mandado de segurança no prazo de 30 (trinta) dias a contar da ciência comprovada da impetração da segurança coletiva. § 2º mandado de segurança coletivo, a liminar só poderá ser concedida após a audiência do representante judicial da pessoa jurídica de direito público, que deverá se pronunciar no prazo de 72 (setenta e duas) horas".

22 BRASIL. Lei n. 13.105, de 16 de março de 2015. Código de Processo Civil. Brasília, 2015. Disponível em: http:// www.planalto.gov.br/ccivil_03/_ato2015-2018/2015/lei/113105.htm. Acesso em: 11 jul. 2020.

23 PASSOS, J. J. Calmon de. O mandando de segurança contra atos jurisdicionais: tentativa de sistematizando nos cinqüenta anos de sua existência. In Ensaios e artigos. Fredie Didier Jr e Paula Sarno Braga (orgs). Salvador: JusPODIVM, 2014. Vol. I. págs. 287-312. Texto retirado da Revista de Processo, vol. 33, jan/1984. 
direito de impetrar segurança jurídica; Petição inicial; Liminar; O procedimento; Decisão; Recursos; A coisa julgada, A litispendência e; A execução.

Em sua conhecida humildade ${ }^{24}$ e simplicidade, Calmon de Passos ${ }^{25}$ inicia seu estudo aludindo que se houvesse somente a previsão do mandado de segurança individual na Constituição da República Federativa do Brasil, nada haveria para ele escrever, o que muda quando o texto constitucional faz referência ao mandado de segurança coletivo, no art. $5^{\underline{o}}$, LXX, que, para o jurista, não se trata de uma nova garantia, mas de uma velha, já conhecida do público, mas com roupagem nova, ampliada pela legitimação, repercutindo no procedimento e sobre a decisão de mérito nele proferida ${ }^{26}$.

Ao ainda escrever sobre modificações significativas, refuta a tese de que havia alteração nos pressupostos de admissibilidade ${ }^{27}$ do mandado de segurança individual para o coletivo, demonstrando as razões pelas quais não foi convencido dessa diretriz, mostrando muito de sua veia crítica, característica que lhe é peculiar. Para desconstruir a tese da modificação dos pressupostos de admissibilidade, divide suas razões em várias partes muito bem argumentadas, demonstrando-se algumas delas a partir desse ponto.

A primeira das objeções está no fato de que uma interpretação literal do dispositivo se preocupa em apontar os sujeitos que são autorizados a impetrar a segurança coletiva, não definindo o que seja o writ, tampouco lhe indicando os pressupostos que anteriormente foram prescritos no inciso LXIX. Isso limita a percepção de que o inciso LXX aponta em suas alíneas que pode impetrar a segurança em nome de outrem, como substitutos, não dispensando as exigências já descritas no inciso anterior.

Uma segunda crítica que acaba enfrentando é a de que no mandando de segurança individual há a expressa referência à palavra direito, sendo que, na alínea $b$ do inciso LXX existe a palavra interesse, que seria diferente de direito, o que faria, em assim aceitando tal diferença, nas palavras de Calmon, com que no mandado de segurança individual se protegesse direitos subjetivos; e no mandado de segurança coletivo, o âmbito de proteção fossem os interesses, sendo diversos, então, os objetos dos writs ${ }^{28}$.

24 PASSOS, Calmon. Esboço de uma teoria das nulidades aplicada às nulidades processuais. Rio de Janeiro: Forense, 2001. p. 3. Essas palavras de revisitação de seu pensamento marcam bem sua simplicidade: "Hoje, já octogenário, alimento a pretensão de revisitar tudo quanto pensei no passado em termos de saber jurídico, tentando colocar o que fui em consonância com o que sou - um estudioso apaixonado do Direito que viveu a experiência de sua aplicação e de sua formulação teórica neste turbulento meio século em que todas as nossas certezas foram abaladas. Vejo essa exigência de ‘revisitação' presente em nosso tempo como algo de natureza vital e se já não disponho de tempo suficiente para isso, apresso-me no fazêlo. O que tenho produzido ultimamente constitui o 'meu testamento intelectual'. Por meio dele, tento transmitir aos que prosseguirão as migalhas que acumulei. Mesmo sendo pouco, não quero reter nada, pois tudo quanto retemos é como se nunca tivéssemos possuído. Se migalhas não alimentam os homens, elas matam a fome dos pássaros que, leves e alados, delas se nutrem e são um belo ordenamento na paisagem dos homens".

25 PASSOS, J. J. Calmon de. Mandado de segurança coletivo, mandado de injunção, habeas data: constituição e processo. Rio de Janeiro: Forense, 1989. p. 6-7. Escreve: "Não haveria, portanto, algo novo a escrever sobre mandado de segurança, caso a Carta de 1988 se limitasse ao inciso LXIX referido. Ocorre que, no inciso imediato, o de número XXX, diz ela, textualmente: 'O mandado de segurança coletivo pode ser impetrado por: a) partido político com representação no Congresso Nacional; b) organização sindical, entidade de classe ou associação legalmente constituída e em funcionamento há pelo menos um ano, em defesa dos interesses de seus membros e associados. Aqui, toda a novidade”.

26 PASSOS, J. J. Calmon de. Mandado de segurança coletivo, mandado de injunção, habeas data: constituição e processo. Rio de Janeiro: Forense, 1989. p. 7. Aduz: "Não se cuida, cumpre de logo dizer e fundamentar, de uma nova garantia constitucional. Estamos diante do velho mandando de segurança, ampliado em termos de legitimação para sua propositura, dessa legitimação nova resultando repercussões sobre a estrutura do procedimento e sobre a decisão de mérito nele proferida”.

27 PASSOS, J. J. Calmon de. Mandado de segurança coletivo, mandado de injunção, habeas data: constituição e processo. Rio de Janeiro: Forense, 1989. p. 7. Escreve: "Diversamente se tem procurado entender, parecendo a alguns tratarse de uma espécie de mandando de segurança modificado no particular dos pressupostos de sua admissibilidade. As razões não nos convenceram".

28 PASSOS, J. J. Calmon de. Mandado de segurança coletivo, mandado de injunção, habeas data: constituição e processo. Rio de Janeiro: Forense, 1989. p. 8. Aduz: "Ainda a nível de interpretação gramatical, dizem os que divergem de nosso entendimento que a alínea b do inciso LXX fala, não em direito, como faz o inciso LXIX, sim em interesses, o que seria coisa diversa”, e finaliza: "Radicalizando a interpretação gramatical, teríamos a seguinte conclusão: mandado de segurança individual diz respeito a direito subjetivo, mandando de segurança coletivo é pertinente a interesses; são diversos, pois, em seu objeto". 
Mais uma vez, Calmon de Passos critica, aludindo ao fato de que a interpretação gramatical é quase que indigente, tendo que haver avanços para a adequada compreensão do tema ${ }^{29}$. Com essa visão, defende que tanto no mandado de segurança individual como o coletivo os direitos defendidos são os mesmos, tendo sido uma solução inteligente proporcionada pela Constituição Federal ao meramente positivar que, ao invés de cada sujeito, sozinho ou litisconsorciado ir à juízo, fez-se uma opção de alargamento de acesso ao mesmo direito por uma entidade que aglutina o direito de todos, ofertando economia, celeridade, coerência e inúmeras outras vantagens num só writ ${ }^{30}$.

Ainda tentando aparar as arestas das críticas sobre direitos e interesses, afirma que a parte que entende dessa forma defende que, em verdade, presta-se um tipo diferente de tutela, pois, por meio do mandamus, estar-se-ia a proteger interesses coletivos, difusos, transindividuais ou outros quaisquer, referindo que esses pensamentos apenas querem balburdiar o instituto do mandado de segurança, não trazendo benefício prático algum, como tenta desconstruir logo após em seu pensamento ${ }^{31}$. Para tanto, começa a direcionar seu pensamento para a expressão interesse, demonstrando sua inter-relação entre ele e o sujeito, sendo uma necessidade por ele experimentada e com vínculo estabelecido entre um e outro ou, numa segunda concepção, como sendo a atitude do sujeito em relação ao bem por ele desejado, libertando-o dessa carência. Continua Calmon a apostar argumentativamente na expressão interesse como algo a ser resolvido pelo direito, por imposição, satisfazendo esse interesse mediante submissão coercitiva do sujeito obrigado, revestindo-se, pois, na natureza jurídica de direito. Assim, para Calmon, seria inadequado, a partir da ambígua definição da expressão interesse, deixá-lo ao relento, pois há nele a configuração de um direito, assim como de direito subjetivo lato sensu, até em razão de este ser uma construção dogmática jurídica antecedente ao Estado de Direito, ligando-o à noção de apropriação de determinado bem ${ }^{32}$. Para Calmon, em passagem lúcida sobre a vida no alvorecer do século XXI, aposta na desautorização daqueles que pensam na dualidade terminológica entre interesses para designar o

29 PASSOS, J. J. Calmon de. Mandado de segurança coletivo, mandado de injunção, habeas data: constituição e processo. Rio de Janeiro: Forense, 1989. p. 8. Afirma: "Sabemos todos, entretanto, que a interpretação gramatical é bem pobre, quase indigente".

30 PASSOS, J. J. Calmon de. Mandado de segurança coletivo, mandado de injunção, habeas data: constituição e processo. Rio de Janeiro: Forense, 1989. p. 8. Escreve: "Entendemos, diversamente, que os direitos que podem ser objeto do mandado de segurança coletivo são os mesmos direitos que comportam defesa pelo mandado de segurança individual. Aqui, ao invés de se exigir que cada sujeito, sozinho ou litisconsorciado, atue em juízo na defesa de seu direito (individual), a Carta Magna proporcionou a solução inteligente e prática de permitir que a entidade que os aglutina, mediante um só writ, obtenha a tutela do direito de todos. Economia processual, celeridade, coerência de decisões etc., inúmeras vantagens somadas, com poucos riscos de prejuízo individual, e assim mesmo remediáveis, como veremos".

31 PASSOS, J. J. Calmon de. Mandado de segurança coletivo, mandado de injunção, habeas data: constituição e processo. Rio de Janeiro: Forense, 1989. p. 8-9. Inicia assim: "Para outros, teríamos aqui um tipo diferente de tutela. Cuidar-se-ia não do direito que individualmente pode ser exercitado, pelo mandamus, sim de interesses coletivos, difusos, transindividuais etc., algo diverso e diferenciado", e finaliza: “Data venia, o que se obtém com esse entendimento é apenas balburdiar, desnecessariamente, o instituto do mandado de segurança, sem disso resultarem benefícios de ordem prática”.

32 PASSOS, J. J. Calmon de. Mandado de segurança coletivo, mandado de injunção, habeas data: constituição e processo. Rio de Janeiro: Forense, 1989. p. 9-10. Inicia: “Ainda quando a expressão 'interesse' comporte compreensões diversificadas, o certo é que ele reclama, necessariamente nos reportemos a um sujeito, a uma necessidade por ele experimentada, e ao vínculo que se estabelece entre um e outra. Sujeito, bem, necessidade (carência) são os dados essenciais para a compreensão do que seja 'interesse'. Donde permanecemos fiéis ao entendimento de que interesse é a relação que se estabelece entre um sujeito e o bem por ele, sujeito, considerado apto para satisfazer sua necessidade, podendose, por conseqüência, subjetivamente, entender interesse também como a atitude do sujeito em relação ao bem por ele tido como adequado para libertá-lo da carência (necessidade) que experimenta", e continua: "Vivendo e convivendo, o homem sente necessidades que geram nele interesse na apropriação, fruição ou utilização de bens que procura obter em nível suficiente para satisfazê-lo (liberá-lo das carências experimentadas). Quando o bem perseguido pelo homem, para atendimento de sua necessidade, coloca-se fora de seu alcance, porque outro homem a isso pôs obstáculo, instaura-se um conflito de interesses, social e individualmente indesejado. O direito foi a técnica elaborada pelos homens para a solução civilizada desses conflitos. Definindo no caso concreto ou dispondo previamente, mediante formulações genéricas, qual o interesse que deve prevalecer, a ordem jurídica põe para determinados sujeitos situações de vantagem, correspectivamente determinando, para os que com ele conflitam, situações de desvantagem. Àquela posição de vantagem denominamos de direito e à correlativa posição de desvantagem nomeamos de dever”, e finaliza: "Quando, portanto, um sujeito, portador 


\section{transindividual e direito para designar o individual ${ }^{33}$.}

Isso, de forma alguma para Calmon de Passos, diminui o indivíduo, desqualificando-o. Na realidade, nas palavras do jurista, essa legitimação o fortalece, não deixando sua vontade enfraquecida perante um grupo, cuja vontade é representada pela entidade personalizada. Não, cabe ao indivíduo a decisão sobre seu interesse, sobre seu futuro, o que muda nos casos ele esteja ineliminavelmente imbricado com idêntico interesse dos outros, pois não é lhe dado o direito de sacrificar o de muitos, tampouco é dado o direito desses muitos sufocar a liberdade de um só ${ }^{34}$.

Conduz ainda seu pensamento Calmon de Passos nessa primeira parte do capítulo de mandado de segurança coletivo dialogando com o tema dos direitos e interesses e o alcance das autorizações elencadas no texto constitucional ligadas a questão de representação e legitimidade, quando situa três grandes permissões que, a seu ver, não podem ser confundidas:

A Constituição permite distinguir três situações que não podem ser confundidas: a) a impetração, pela entidade, do mandado de segurança em seu próprio favor, na defesa de direito público subjetivo que seja titular; b) a impetração, pela entidade, de mandando de segurança em favor de associados, porque expressamente autorizada por eles na espécie; aqui, pode a entidade agir sem qualquer limitação ou vínculo, porque o objetivo do inciso XXI do art. $5^{\text {o }}$ da CF foi proporcionar o apoio (serviço)da entidade ao associado, nos limites em que o associado julga conveniente esse apoio; c) a impetração, pela entidade, de mandando de segurança coletivo em favor de seus membros ou associados, como substituta processual e independente de autorização deles, por estarem em jogo direitos (individuais) de associados seus, direitos esses que guardam certo vínculo com os fins mesmos da entidade (interesse qualificador do vínculo associativo) ${ }^{35}$.

Para defender seu posicionamento, exemplifica por meio de possíveis mandados de segurança impetrados pela Ordem dos Advogados do Brasil ${ }^{36}$.

de determinado interesse, dispõe, na ordem jurídica, de algum instrumento mediante cuja utilização ele pode ter, impositivamente, satisfeito seu interesse, com a submissão (coercitiva) da vontade do sujeito obrigado, aquele interesse necessariamente se reveste da natureza de um direito, direito que, por motivo de ser particularizável em determinado sujeito como situação de vantagem que lhe é assegurada, reveste-se da qualificação de direito subjetivo (em sentido lato)".

33 PASSOS, J. J. Calmon de. Mandado de segurança coletivo, mandado de injunção, habeas data: constituição e processo. Rio de Janeiro: Forense, 1989. p. 10-11. Escreve: "A democracia social, o welfare state, a sociedade de massa, o fenômenos da urbanização e das megalópolis, o perecimento da sociedade dos vizinhos e o nascer da sociedade da solidão das casas e do congestionamento das ruas, a socialização da agressão, que deixou de ser um problema de alguns para se fazer preocupação de todos, a coletivização das carências, hoje igualmente compartilhadas por milhares de seres humanos, solidários no infortúnio e tão solidários na ventura, tudo isso levou à proteção jurídica de interesses, necessidades, carências que, permanecendo individuais, por dizerem respeito a pessoas bem caracterizadas, os Josés e as Marias da vida (e desse prisma são direitos individuais), por igual se revestem do caráter de interesses, necessidades, carências coletivas, porque compartilhadas em termos idênticos por uma série de pessoas, às vezes até insuscetíveis de determinação precisa. E nem por serem transindividuais ou coletivos, ou sociais, esses interesses deixam de ser conteúdo de direitos, inclusive em sua dimensão subjetiva. A dualidade de terminologia (interesses, no transindividual; direito, no individual) é de todo desautorizada, apenas traduzindo o remanescente conservador (mesmo inconsciente) dos que ainda não lograram se libertar da estreita cela em que foi aprisionada a noção clássica de direito subjetivo".

34 PASSOS, J. J. Calmon de. Mandado de segurança coletivo, mandado de injunção, habeas data: constituição e processo. Rio de Janeiro: Forense, 1989. p. 15. Aduz: "Ao indivíduo cabe decidir sobre seu próprio interesse, salvo quando a defesa desse interesse está ineliminavelmente imbricada na defesa de interesse idêntico de outros, quando a um não é dado sacrificar a muitos como a muitos não se concede sufocar a liberdade de um só”.

35 PASSOS, J. J. Calmon de. Mandado de segurança coletivo, mandado de injunção, habeas data: constituição e processo. Rio de Janeiro: Forense, 1989. p. 13.

36 PASSOS, J. J. Calmon de. Mandado de segurança coletivo, mandado de injunção, habeas data: constituição e processo. Rio de Janeiro: Forense, 1989. p. 14. Escreve: "Exemplificando. A Ordem dos Advogados do Brasil pode impetrar mandado de segurança para que lhe seja reconhecido o direito de participar da seleção de magistrados, porque isso lhe foi assegurado no art. 23, I, da Constituição Federal (a). Ela pode, devidamente autorizada por seu membro, impetrar mandado de segurança em nome dele, representando-o, por exemplo, para fazer valer o seu direito de ter reajustadas as prestações devidas ao Sistema Financeiro de Habitação, segundo o plano da equivalência salarial, e nada impede que a OAB represente dez, vinte ou cinqüenta de seus membros, com direito dessa mesma espécie, se por todos autorizada. Eles serão também parte no mandamus, substituídos pela OAB, parte, como substituta, legitimada nos termos do art. 5o , XXI, da CF, impondose, na inicial, a referência nominal aos substituídos e prova da respectiva autorização (b). Finalmente, pode ela impetrar 
No segundo momento de seu livro, no capítulo pertinente ao tema do mandado de segurança coletivo, Calmon passa a expor aspectos mais ligados aos pressupostos processuais e condições da ação no writ, depois a questão da decadência, da petição inicial, da liminar, chagando, então, na parte que começa a escrever sobre o procedimento, dividido em rito, informações do coator, o pronunciamento do Ministério Público, a intervenção de terceiros, a decisão, os recursos, a coisa julgada, a litispendência e a execução.

Todos assuntos de imensa importância prática, com muita reflexão por parte de Calmon, mas que foge ao núcleo principal do objeto do estudo que foi trabalhar com o que entendia ser o mandamus coletivo.

\section{Considerações Finais}

As ideias de Calmon de Passos defendidas na obra Mandado de segurança, mandado de injunção, habeas data: processo e constituição devem ser estudadas. Jurista à frente de seu tempo, escreveu sobre um tema um ano após ser inserido no texto da Constituição de 1988 como uma das ações constitucionais em defesa do indivíduo frente ao Estado, limitando seu poder, um dos pontos mais sensíveis de pensamento.

No cerne de seu pensamento no livro, aposta ser o mandado de segurança coletivo a mesma garantia constitucional do mandado de segurança individual, apenas aumentando seu campo de abrangência por meio da legitimação de associações, entidades ou partido político para a defesa de seus representados. Para tentar convencer seu leitor, passa tanto por interpretações mais básicas do texto constitucional até as mais complexas, defendendo que os direitos a serem defendidos no individual são os mesmos no coletivo, mesmo que neste se faça alusão à interesses na alínea $b$ e não a direitos como no inciso LXIX do art. $5^{\circ}$.

Que tributos assim sejam mais presentes!

Mais uma vez parabéns a todos e a todas que se envolveram no Congresso e que organização tão bela homenagem nessa obra, esperando que essas linhas escritas sobre Calmon de Passos possam, de uma forma mesmo que mínima, homenageá-lo.

\section{Referencial Teórico}

ARAÚJO, José Henrique Mouta. Mandado de segurança. 8. Ed. Salvador: JusPODIVM, 2021. ASSOCIAÇÃO NORTE NORDESTE DE PROFESSORES DE PROCESSO.

ANNEP Associação. Canal no YouTube. [S.l.: s.n.], 19 maio 2020. Disponível em: https://www.youtube. com/channel/UCEtAWMGXrTwabGQ0wxcjdOg. Acesso em: 11 jul. 2020.

BRAGA, Paula Sarno. Norma de processo e norma de procedimento: o problema da repartição de competência legislativa no direito constitucional brasileiro. Salvador: Juspodivm, 2015.

BRASIL. Constituição (1988). Constituição da República Federativa do Brasil de 1988. Brasília, 1988. Disponível em: http://www.planalto.gov.br/ccivil 03/constituicao/constituicao.htm. Acesso em: 11 jul. 2020.

BRASIL. Lei n. 5.869, de 11 de janeiro de 1973. Institui o Código de Processo

Civil. Brasília, 1973. Disponível em: http://www.planalto.gov.br/ccivil_03/leis/15869impressao.htm. Acesso em: 11 jul. 2020.

mandado de segurança coletivo para assegurar a seus associados o recebimento de processos, com vistas, fora do cartório, afastando a ilegalidade de um Provimento da Corregedoria que determinou a permanência dos autos em cartório, vetando sua retirada mesmo por advogados e em qualquer hipótese. Para isso, independe de autorização de seus associados. Aqui ela é parte única no writ, agindo como substituta processual, legitimada pelo art. 5º, inciso LXX, alínea b, da CF desnecessária e até inconveniente a referência nominal dos substituídos (c)”. 
BRASIL. Lei n. 12.016, de 7 de agosto de 2009. Disciplina o mandado de segurança individual e coletivo e dá outras providências. Brasília, 2009. Disponível em: http://www.planalto.gov.br/ ccivil_03/ato2007-2010/2009/lei/112016.htm. Acesso em: 11 jul. 2020.

BRASIL. Lei n. 13.105, de 16 de março de 2015. Código de Processo Civil. Brasília, 2015. Disponível em: http://www.planalto.gov.br/ccivil_03/_ato20152018/2015/lei/113105.htm. Acesso em: 11 jul. 2020.

DIDIER JR., Fredie. Pressupostos processuais e condições da ação: o juízo de admissibilidade do processo. São Paulo: Saraiva, 2005.

JOBIM, Marco Félix. Cultura, escolas e fases metodológicas do processo. 4. ed. Porto Alegre: Livraria do Advogado, 2019.

O QUE é justo? - J. J. Calmon de Passos. 1 vídeo, 1h07min22s. Publicado pelo canal Diego Sousa. [S.l.: s.n.], 30 dez. 2016. Disponível em: https://www.youtube.com/watch?v=fUAu8DnHEuo. Acesso em: 11 jul. 2020.

NOGUEIRA, Pedro Henrique. Negócios jurídicos processuais. 4. ed. Salvador: Juspodivm, 2020.

PASSOS, Calmon. Esboço de uma teoria das nulidades aplicada às nulidades processuais. Rio de Janeiro: Forense, 2001.

PASSOS, J. J. Calmon de. A ação no direito processual civil brasileiro. Salvador: Juspodivm, 2014.

PASSOS, J. J. Calmon de. Comentários ao Código de Processo Civil (arts. 270331). 9. ed. Rio de Janeiro: Forense, 2004, v. 3.

PASSOS, J. J. Calmon de. O mandando de segurança contra atos jurisdicionais: tentativa de sistematizando nos cinqüenta anos de sua existência. In Ensaios e artigos. Fredie Didier Jr e Paula Sarno Braga (orgs). Salvador: JusPODIVM, 2014. Vol. I. págs. 287-312.

PASSOS, J. J. Calmon de. Revisitando o direito, o poder, a justiça e o processo: reflexões de um jurista que trafega na contramão. Salvador: Juspodivm, 2012.

PASSOS, J. J. Calmon de. Ensaios e artigos. Salvador: Juspodivm, 2014, v. 1.

PASSOS, J. J. Calmon de. Ensaios e artigos. Salvador: Juspodivm, 2016, v. 2.

PASSOS, J. J. Calmon de. Mandado de segurança coletivo, mandado de injunção, habeas data: constituição e processo. Rio de Janeiro: Forense, 1989.

PASSOS, J. J. Calmon de. O que é justo? Palestra. Disponível em: https://www.youtube.com/ watch? $\mathrm{v}=$ fUAu8DnHEuo. Acesso 11 nov. 2020.

QUEIROZ, Pedro Gomes de. Mandado de segurança: propostas para duração razoável e efetividade. Salvador: JusPODIVM, 2018.

ZANETI Jr., Hermes. O ‘novo’ mandado de segurança coletivo. Salvador: JusPODIVM, 2013. 